\title{
Fusarium Crown and Root Rot of Tomato in Florida ${ }^{1}$
}

\author{
Shouan Zhang, Pamela D. Roberts, Geoffrey Meru, Robert J. McGovern, and Lawrence E. \\ Datnoff ${ }^{2}$
}

Fusarium crown and root rot, caused by the fungus

Fusarium oxysporum f. sp. radicis-lycopersici (FORL) was first detected in Florida in 1974. The disease has been reported in all major tomato growing areas of the state, but is particularly serious in the acidic, sandy soils of Florida's southern production regions. Fusarium crown and root rot has also occurred in Canada, Mexico, Israel, Japan, many countries in Europe, and other states in the USA including California, New Hampshire, New Jersey, New York, Ohio, Pennsylvania, and Texas. It is a serious problem for seedling and greenhouse fruit production and can cause significant yield decreases in field-grown, staked tomatoes in Florida.

\section{Symptoms}

The fungus invades susceptible plants through wounds and natural openings created by newly emerging roots. Early symptoms caused by FORL in tomato seedlings include yellowing, stunting, and premature loss of cotyledons and lower leaves. A pronounced brown lesion that girdles the hypocotyl (root/shoot junction), root rot, wilting, and death are advanced symptoms of this disease (Figure 1).

Infected plants in the field may be stunted, and as they begin to heavily bear fruit, their lower leaves turn yellow and wilt. Wilting first occurs during the warmest part of the day, and plants appear to recover at night. Infected plants may either totally wilt and die or persist in a weakened state, producing reduced numbers of inferior fruit (Figure 2).

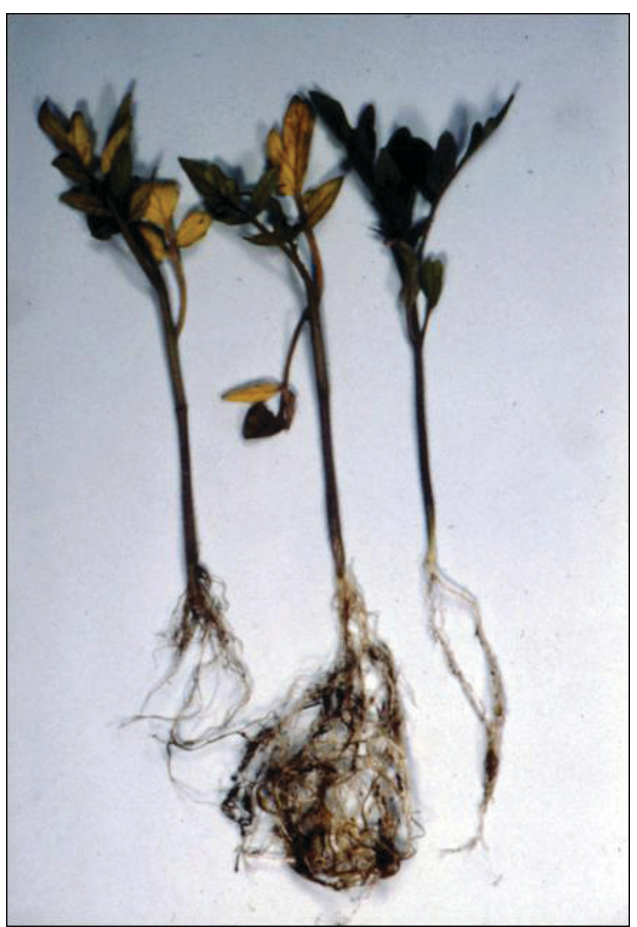

Figure 1. Infected tomato transplants (left and center) next to healthy transplant (right).

The taproot of infected plants often rots entirely, and chocolate brown cankers appear at the soil line (Figure 3). When diseased plants are sectioned lengthwise, extensive brown discoloration and rot are evident in the cortex of the

1. This document is PP52 (formerly SP184.), one of a series of the Plant Pathology Department, UF/IFAS Extension. Original publication date September 2001. Revised June 2015 and December 2021. Visit the EDIS website at https://edis.ifas.ufl.edu for the currently supported version of this publication.

2. Shouan Zhang, professor, Plant Pathology Department, UF/IFAS Tropical Research and Education Center; Pamela D. Roberts, professor, Plant Pathology Department, UF/IFAS Southwest Florida Research and Education Center; Geoffrey Meru, assistant professor, Horticultural Sciences Department, UF/IFAS Tropical Research and Education Center; Robert J. McGovern, retired professor, Plant Pathology Department; Lawrence E. Datnoff, former professor, Plant Pathology Department; UF/IFAS Extension, Gainesville, FL 32611.

The Institute of Food and Agricultural Sciences (IFAS) is an Equal Opportunity Institution authorized to provide research, educational information and other services

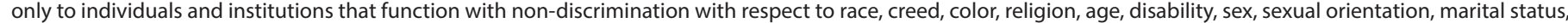

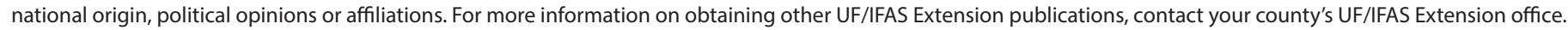
U.S. Department of Agriculture, UF/IFAS Extension Service, University of Florida, IFAS, Florida A \& M University Cooperative Extension Program, and Boards of County Commissioners Cooperating. Andra Johnson, dean for UF/IFAS Extension. 
crown and roots (Figure 4). In comparison with the related fungus F. oxysporum f. sp. lycopersici (FOL), which causes Fusarium wilt, FORL produces less extensive discoloration in the plants' water-conducting tissue; the brown streaks observed, extend less than 20 to $30 \mathrm{~cm}$. (8 to 12 in.) above the soil line. Round, brown lesions are evident at the origins of rotted lateral roots. An abnormal proliferation of adventitious roots may occur above the infected region. The fungus produces masses of white mycelium and yellow to orange spores in necrotic stem lesions on dead and dying plants.

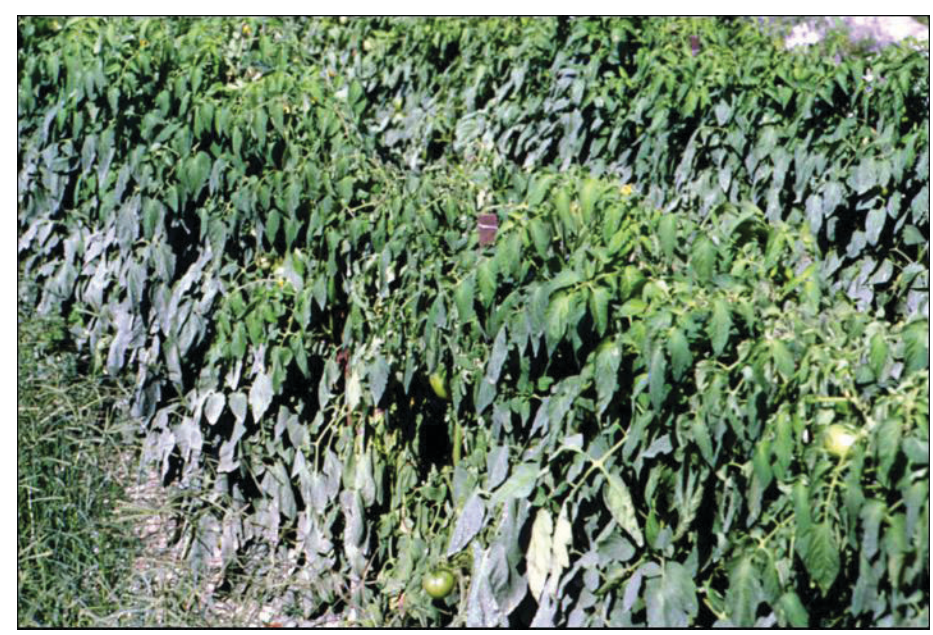

Figure 2. Wilted tomato plants infected with Fusarium crown rot fungus.

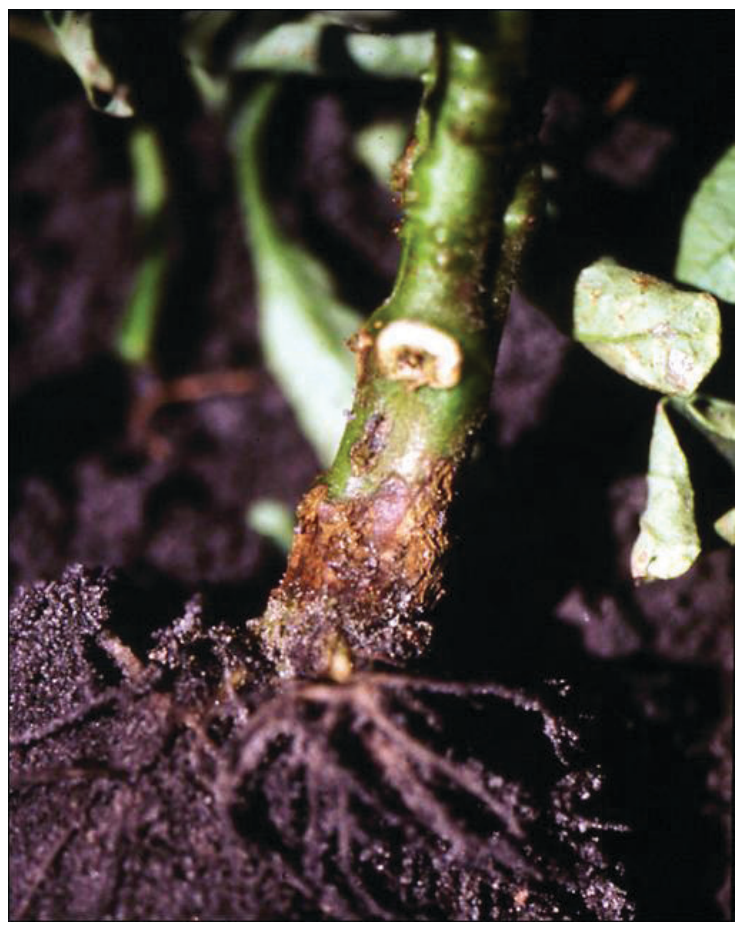

Figure 3. Canker on stem at soil line.

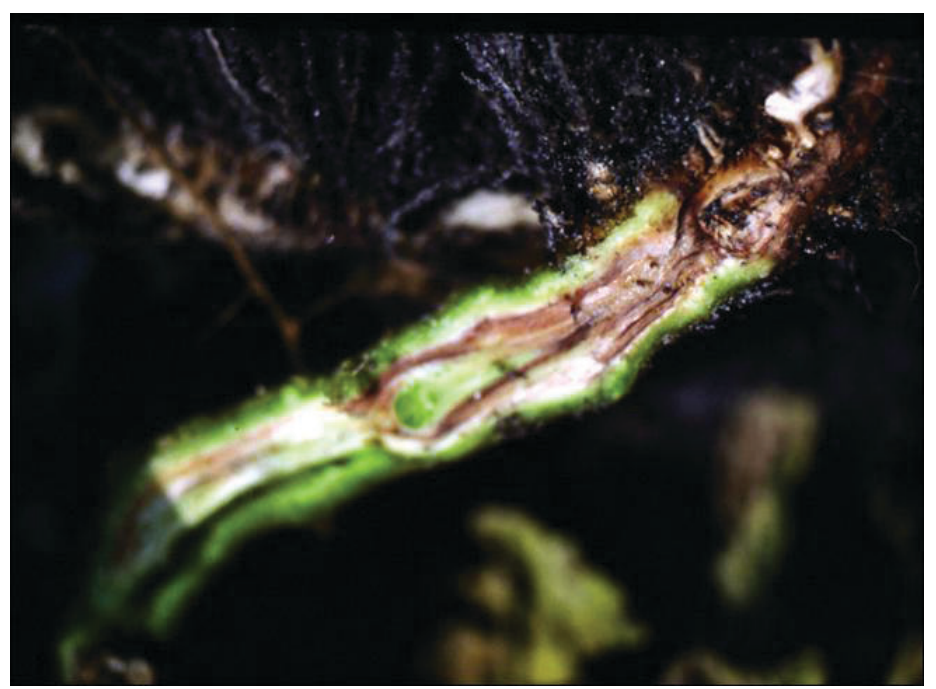

Figure 4. Internal discoloration of the crown and root rot. (Note missing taproot).

\section{Ecology and Epidemiology}

In further contrast to Fusarium wilt, crown and root rot is favored by cool temperatures $\left(10^{\circ} \mathrm{C}\right.$ to $20^{\circ} \mathrm{C} / 50^{\circ} \mathrm{F}$ to $\left.68^{\circ} \mathrm{F}\right)$. Low soil $\mathrm{pH}$, ammoniacal nitrogen, and water-logged soil also exacerbate the disease. The causal fungus produces three types of spores: macroconidia, microconidia and chlamydospores. The latter two types of spores play a prominent role in the survival and spread of FORL. Microconidia form in great abundance in necrotic tissue, are spread by air currents, and readily reinfest soil sterilized by heat or broad spectrum biocides such as fumigants. Chlamydospores have thicker walls and enable the fungus to survive in the soil and wooden stakes for more than one cropping season.

Lateral spread of the fungus from plant to plant is primarily by root contact as evidenced by the clustering of symptomatic plants within beds. Movement of the fungus in the soil in the absence of roots is minimal $(<2.5 \mathrm{~cm} / 1$ in.). Long-range dissemination of FORL can occur through infected transplants and perhaps via chlamydospores in soil particles on contaminated shoes, plant stakes, machinery, transplant trays, and other equipment.

Analysis of a population of FORL isolates by vegetative compatibility grouping (VCG) and molecular techniques showed that VCG 0094 is predominant in Florida. Two other VCGs, 0091 and 0098, are present at low frequencies. Within the VCG 0094 population, isolates from the east coast are distinct from west coast. The results of VCG and genetic analysis indicate that FORL was probably introduced in Palm Beach Co., FL and moved to other parts of the state and probably also to Europe. 


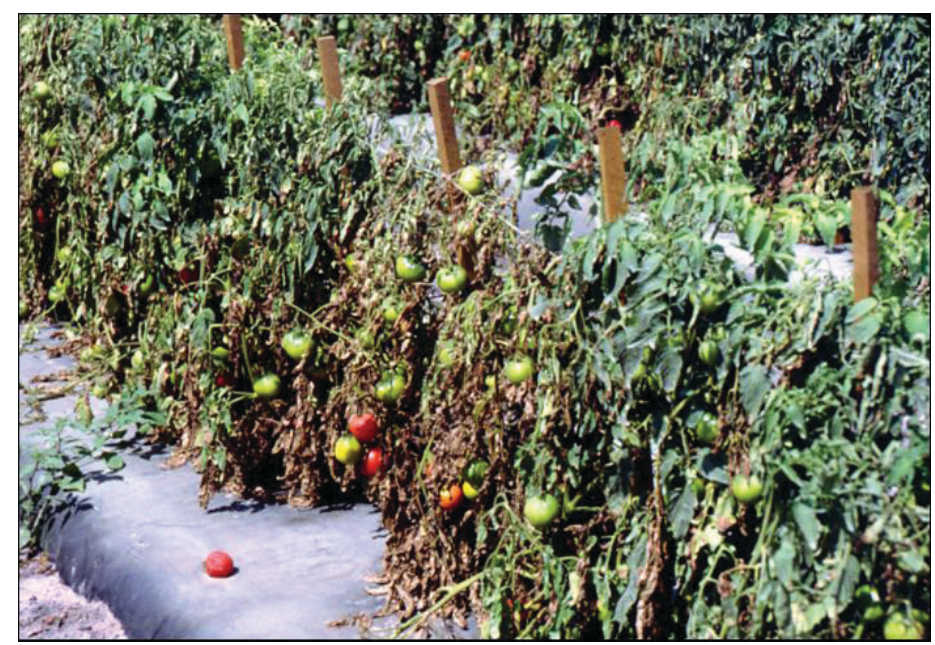

Figure 5. Lateral spread of Fusarium oxysporum f.sp. radicis-lycopersici within a planting bed.

Resistance has been successfully bred into a number of greenhouse and field tomatoes. The fungus may also infect and cause small lesions in the roots of pepper and eggplant, but apparently does not infect potato. Surprisingly, many non-solanaceous plants, including spinach, beets, legumes, and certain cucurbits may be infected by FORL. The fungus has also been isolated either naturally or experimentally from the roots of a number of weeds, including Brazilian pepper (Schinus terebinthifolius), carpet weed (Mollugo verticillata), chickweed (Stellaria media), corn spurry (Spergula arvense), cudweed (Gnaphatium sp.), curly dock (Rumex crispus), narrow leaved plantain (Plantago lanceolata), redroot pigweed (Amaranthus retroflexus), Scoparia sp., shepards purse (Capsella bursa-pastoris), and wild buckwheat (Polygonum convulvulus). Monocots, such as corn, apparently are not susceptible to this fungus.

\section{Integrated Management}

At present, Fusarium crown and root rot is difficult to control in field-grown tomatoes because the pathogen rapidly colonizes sterilized soil and persists for long periods. However, an integration of the following management procedures may help to reduce the impact of crown and root rot:

1. Use disease-free transplants. Transplant houses should not be located near tomato production fields. Avoid over watering, which makes the transplants more susceptible to crown and root rot. Disinfect transplant trays by steaming before reuse.

2. Use a preplant fumigant. The soil should be of good tilth and adequately moist for at least two weeks prior to fumigation. Use an appropriate chisel spacing and depth, and immediately cover the bed with plastic mulch following fumigation.

\section{Optimize cultural practices in the field. Avoid injuring} transplants when they are set in the field. Physical damage and injury from excessive soluble salts may make young plants more susceptible to crown and root rot. The use of water drawn from wells rather than ditches for watering-in transplants may help to prevent recontamination of fumigated soil. Avoid ammoniacal nitrogen and maintain the soil $\mathrm{pH}$ at 6 to 7 . Rapidly plow in crop debris following final harvest. Disinfest tomato stakes before reuse or use new stakes.

4. Rotate with a non-susceptible crop. Incomplete knowledge of the host range of FORL makes precise recommendations in this area difficult. Current research data suggest that leguminous crops should be avoided in favor of corn and similar crops. Rotation and intercropping with lettuce had reduced FORL in greenhouse-grown tomatoes.

5. Significant progress has been made in breeding for resistance to Fusarium crown and root rot in field-grown tomatoes. Although the commonly used commercial varieties do not have resistance, some resistant cultivars, such as 'Conquest', are available for field use.

6. In FORL hotspots, susceptible cultivars may be grafted onto resistant rootstocks to prevent heavy crop loss.

7. For greenhouse production, plant seedlings in sterilized soil.

8. Additional management strategies under investigation include the use of biological control, cover crops, and soil solarization alone or in combination with fumigants. 